\title{
EDUCATIONAL LEADERSHIP FOR THE 21ST CENTURY
}

Variance on educational leadership conceptualizations exist. The labels used in this field have evolved from 'educational administration' to 'educational management' and, now, to 'educational leadership' (Bush, 2011; Gunter, 2004). The language of leadership has joined or rather superseded the concept of management, leading Yukl (2002; p. 4-5) to argue that the 'definition of leadership is arbitrary and very subjective. Some definitions are more useful than others, but there is no "correct" definition'.

Dimmock (1999; p. 442) acknowledges there are competing definitions between administration, leadership and management while also differencing these concepts:

Leaders [experience] tensions between competing elements of leadership, management, and administration. Irrespective of how these terms are defined, leaders experience difficulty in deciding the balance between higher order tasks designed to improve staff, student and performance (leadership), routine maintenance of present operations (management) and lower order duties (administration).

The many definitions and conceptualizations has resulted in the dramatic growth of research over the past 10 years in developing societies to describe and analyze educational leadership and management practices (Hallinger, 2017; Oplatka \& Arar 2017; Hallinger \& Chen, 2015; Hallinger \& Bryant, 2013) meanwhile the combined forces of information technology, globalization and knowledge-driven economy has brought upon an age of accelerations (McNeill \& Engelke, 2014) catalyzing changes in schools and societies (Friedman, 2016).

Educational leadership stands in the midst of these accelerations. The OECD, through the Education Policy Outlook 2015 (OECD,2015), has highlighted the global trends in 
most education settings in years to come. Interestingly, these trends offer commonality rather than differences among education systems around the world. Driving change in schools, developing and supporting school leaders, adapting teachers to new models of professional development, personalized and blended learning, leveraging on resources and more recently building partnership with the community. Educational leaders face unpreceded accountability pressures in what is clearly a 'results driven' business. As these environmental pressures intensify, leaders and managers require greater understanding, skills and resilience to sustain their institutions.

Botha (2013) stressed that there must first be a major shift in the definition of educational leadership to allow for the reconstruction of thinking, assumptions and practices. Over the last decade, strong efforts are made to ensure upcoming school leaders gain adequate accredited training with hands on experiences in school settings, classroom theoretical exposure, and relevant professional development to prepare them for a role of school leadership (Scot, 2015; Hilliard \& Jackson, 2011).

However, are these exposures adequate for a strong commitment to 21st century learning? This is due to the reality of the present curriculum strongly rooted in the traditions of past centuries which focuses on content knowledge and basic skills. To what extend technology usage is appropriate in the classroom? Are standardized tests appropriate to measure student learning? School systems now demand leaders to be effective instructional leaders. The current issue for education leaders who wrestle with the challenges of promoting 21st century learning can be termed as the "leaders dilemma". 
Educational leaders of the 21 st century is not a requirement but a necessity to ensure 21st century teaching and learning (Reeves, 2011). To this degree, the response of the International Online Journal of Educational Leadership to the age of acceleration is not to join in or to go with the flow, but rather to take up a 'new mission' and 'acquire a new discourse' in educational leadership for the 21st Century.

\section{REFERENCE:}

Botha, R. J. (2013). Epistemological beliefs and leadership approaches among South African school principals. Educational Studies, 39(4), 431-443.

Bush, T. (2011). Theories of Educational Leadership and Management, 4th edn. London: SAGE.

Friedman, T. (2016). Thank you for being late: An optimist's guide to thriving in the age of accelerations. New York: Farrar, Strauss, \& Giroux

Gunter, H. (2004). Labels and labelling in the field of educational leadership. Discourse: studies in the cultural politics of education, 25(1), 21-41.

Hallinger, P. (2017). Revealing a Hidden Literature: Systematic Research on Educational Leadership and Management in Africa. Educational Management Administration \& Leadership. doi:10.1177/1741143217694895.

Hallinger, P., \& Chen, J. (2015). Review of Research on Educational Leadership and Management in Asia: A Comparative Analysis of Research Topics and Methods, 1995- 2012. Educational Management Administration \& Leadership, 43 (1), 5-27

Hallinger, P., \& Bryant, D. (2013). Mapping the Terrain of Educational Leadership and Management in East Asia. Journal of Educational Administration, 51 (5), 618637.

Hilliard, A., \& Jackson, B. T. (2011). Current trends in educational leadership for student success plus facilities planning and designing. Contemporary Issues in Education Research, 4(1), 1-8. 
McNeill, J. R., \& Engelke, P. (2014). The great acceleration: An environmental history of the anthropocene. Cambridge: Harvard University Press.

OECD (2015). Education Policy Outlook 2015: Making Reforms Happen, OECD Publishing, Paris.

Oplatka, I., \& Arar, K. (2017). The Research on Educational Leadership and Management in the Arab World Since the 1990s: A Systematic Review. Review of Education. doi:10.1002/rev3. 3095.

Reeves, D. (2011). Finding your leadership focus: What matters most for students results. New York, NY: Teachers college Press.

Scott, C. L. (2015). The Futures of Learning 3: What kind of pedagogies for the 21st century? UNESCO Education Research and Foresight, Paris. [ERF Working Papers Series, No. 15].

Yukl, G. (2002), Leadership in Organizations, 5th ed., Prentice-Hall, Englewood Cliffs, NJ.

Donnie Adams

Editor of International Online Journal of Educational Leadership Institute of Educational Leadership, University of Malaya donnieadams@um.edu.my and Gopinathan Raman Kutty and Zuliana Mohd Zabidi Institute of Educational Leadership, University of Malaya 